\title{
31. CARBON AND OXYGEN ISOTOPES OF CARBONATES FROM DEPOSITS OF THE MOROCCAN BASIN, DEEP SEA DRILLING PROJECT SITES 415 AND 416
}

\author{
E. M. Galimov, L. A. Bannikova, and L. Ye. Steshenko, V. I. Vernadsky Institute of Geochemistry \\ and Analytical Chemistry, U.S.S.R. Academy of Sciences, Moscow, U.S.S.R.
}

\section{INTRODUCTION}

Holes 415, 415A, and 416A drilled during Leg 50 of the Deep Sea Drilling Project were located at the foot of the West African continental slope within the Moroccan Basin.

The water depth at Hole 415A is 2794 meters. Drilling at the site disclosed an 1079.5-meter-thick sequence ending in upper Albian deposits. The Mesozoic section of Hole $415 \mathrm{~A}$ consists of pelagic calcareous clay with a regular contribution of material from the continental shelf and slope distributed throughout. The contribution of redeposited material decreases upward in the sequence. In the Cenozoic section, clays predominate and are interbedded with chalk and limestone. In the upper portion they pass into nannofossil marl and nannofossil ooze and silt enriched in siliceous material.

Hole 416A (water depth $4191 \mathrm{~m}$ ) penetrated a sedimentary sequence to the depth of 1624 meters. The deepest deposits are Jurassic distal turbidites comprising terrigenous detrital material and redeposited calcareous sediments. Pelagic material is present in lesser amounts. This facies is preserved in the Berriasian and lower part of the Valanginian section. In the upper part of the Valanginian and Hauterivian sediments the calcareous component is sharply reduced; detrital material of continental origin predominates to the top of the Hauterivian and the turbiditic facies gradually diminishes. Pelagic and hemipelagic sediments form the upper parts of the Mesozoic and the Cenozoic section.

On the whole, the sediments of both sites are characterized by an extremely variable lithology indicating a diversity of source areas and depositional environments. The data on the carbon- and oxygen-isotope compositions of the carbonates help us to understand certain aspects of the depositional environments in the Moroccan Basin.

\section{EXPERIMENTAL PROCEDURE}

Dried samples $\left(1 \mathrm{~cm}^{3}\right)$ were ground to powder and heated in a vacuum at $450^{\circ} \mathrm{C}$ for half an hour. The samples were then treated with 100 per cent orthophosphoric acid at a stabilized temperature of $25^{\circ} \mathrm{C}$. Evolved $\mathrm{CO}_{2}$ was analyzed on a Varian MAT-230 mass spectrometer. The experimental error does not exceed \pm 0.1 per mill. $\delta^{13} \mathrm{C}$ values are given relative to the PDB standard; $\delta^{18} \mathrm{O}$ values have been recalculated in terms of the SMOW standard.

\section{RESULTS}

The carbon and oxygen of carbonates from Hole $415 \mathrm{~A}$ have highly variable isotopic compositions. $\delta^{13} \mathrm{C}$ values vary from -6 to +4 per mil. $\delta^{18} \mathrm{O}$ values vary from +22.7 to +30.8 per mill (Table 1$)$. The range of the carbon- and oxygen-isotope compositions of the carbonates in the Hole $416 \mathrm{~A}$ sediments is even more marked (Table 2) Here $\delta^{13} \mathrm{C}$ values vary from -7.6 to 4.5 per mill, and $\delta^{18} \mathrm{O}$ values vary from +16.9 to +32.4 per mill. In the interval between 1250 and 1450 meters sub-bottom, the values of $\delta^{13} \mathrm{C}$ and $\delta^{18} \mathrm{O}$ are minimal.

\section{DISCUSSION}

Analysis of the results shows that the sequences investigated have the following characteristics:

1. The carbonates throughout the sequences are generally enriched in light isotopes of both carbon and oxygen. The isotopically lightest carbonates are found in the upper part of the Valanginian and Hauterivian deposits from Hole 416A.

2. The variation of the $\delta^{18} \mathrm{O}$ and $\delta^{13} \mathrm{C}$ values are clearly parallel in the Mesozoic section of Hole 416A (Figure 1). This relationship, in a somewhat less clearly expressed form, also characterizes the section of Hole 415A (Figure 2). Such parallelism is not manifest in the upper-Cenozoic sediments of both holes. Only a small number of analyses were performed on this part of the section, however, and this observation may not be significant.

TABLE 1

${ }^{13} \mathrm{C} /{ }^{12} \mathrm{C}$ and $18 \mathrm{O} / 16 \mathrm{O}$ of Carbonates, Holes $415,415 \mathrm{~A}$

\begin{tabular}{cclll}
\hline & $\begin{array}{c}\text { Sub-Bottom } \\
\text { Depth } \\
(\mathrm{m})\end{array}$ & \multicolumn{1}{c}{ Stratigraphy } & $\begin{array}{c}\delta^{13} \mathrm{C} \\
(\%)\end{array}$ & $\begin{array}{c}\delta 18 \mathrm{O} \\
(\%)\end{array}$ \\
\hline $415-1-5$ & $0.0-75.0$ & Pleistocene & -0.63 & +24.59 \\
$2-1$ & $74.0-83.5$ & Miocene-Pliocene & -2.62 & +25.63 \\
$3-1$ & $137.5-147.0$ & Middle Miocene & +0.60 & +30.84 \\
$4-5$ & $207.0-216.5$ & Lower Miocene & -1.08 & +29.81 \\
$5-3$ & $273.5-283.0$ & Lower Miocene & & \\
$415 \mathrm{~A}-5-1$ & $443.0-452.0$ & Paleocene & +0.30 & +22.77 \\
$6-1$ & $452.0-509.5$ & Paleocene & -1.94 & +27.60 \\
$8-1$ & $576.0-585.5$ & M.-U. Cretaceous & -0.94 & +24.67 \\
$9-3$ & $642.0-652.0$ & Middle Cenomanian & +1.05 & +28.69 \\
10, CC & $709.0-718.5$ & Middle Cenomanian & +1.46 & +29.55 \\
$12-1$ & $880.0-889.5$ & Middle Cenomanian & +3.99 & +27.01 \\
$13-2$ & $956.0-965.5$ & Lower Cenomanian & -0.21 & +25.11 \\
$14-1$ & $1032.0-1041.5$ & Upper Albian & +2.29 & +27.56 \\
\hline
\end{tabular}

aOne sample measured from each interval. 
TABLE 2

${ }^{13} \mathrm{C} /{ }^{12} \mathrm{C}$ and ${ }^{18} \mathrm{O} / 16 \mathrm{O}$ of Carbonates, Hole $416 \mathrm{~A}$

\begin{tabular}{|c|c|c|c|c|}
\hline Section ${ }^{a}$ & $\begin{array}{l}\text { Sub-Bottom } \\
\text { Depth } \\
\text { (m) }\end{array}$ & Stratigraphy & $\begin{array}{l}{ }^{13} \mathrm{C} \\
(\%)\end{array}$ & $\begin{array}{l}\delta^{180} 0 \\
(\%)\end{array}$ \\
\hline $416 A-1-1$ & $146.0-155.3$ & Miocene & -1.80 & +28.05 \\
\hline $1-1$ & $146.0-155.3$ & Miocene & +0.63 & +32.35 \\
\hline $2-3$ & $298.0-304.5$ & Lower Miocene & -1.51 & +29.41 \\
\hline $3-1$ & $450.0-459.0$ & Upper Oligocene & -3.23 & +24.38 \\
\hline $7-2$ & $896.0-1093.0$ & Hauterivian & +4.50 & +29.25 \\
\hline $10-2$ & $1185.0-1194.0$ & , & +1.93 & +29.29 \\
\hline $12-1$ & $1204.3-1213.8$ & $"$ & -0.67 & +28.04 \\
\hline $14-3$ & $1223.0-1232.0$ & Valanginian & -2.72 & +22.16 \\
\hline $16-2$ & $1242.0-1252.0$ & $"$ & -4.73 & +21.38 \\
\hline $21-4$ & $1290.0-1299.0$ & $"$ & -1.88 & +25.24 \\
\hline $22-2$ & $1299.5-1319$ & $"$ & -7.58 & +16.92 \\
\hline $26-4$ & $1337.0-1346.0$ & $"$ & -1.66 & +26.63 \\
\hline $27-2$ & $1346.0-1356.0$ & $"$ & -3.75 & +24.90 \\
\hline $28-4$ & $1356.0-1365.0$ & $"$ & -4.17 & +22.48 \\
\hline 32.2 & $1394.0-1403.0$ & $"$ & -2.26 & +25.74 \\
\hline $34-1$ & $1406.8-1416.0$ & $"$ & - & - \\
\hline $36-2$ & $1425.0-1435.0$ & $"$ & -2.04 & +25.30 \\
\hline $38-2$ & $1445.0-1450.0$ & $"$ & -4.09 & +22.08 \\
\hline $42-1$ & $1464.0-1473.0$ & $"$ & +0.80 & +28.51 \\
\hline $43-1$ & $1482.0-1491.0$ & $"$ & -1.45 & +26.82 \\
\hline $45-1$ & $1501.0-1510.0$ & $"$ & -0.50 & +27.14 \\
\hline $45-1$ & $1501.0-1510.0$ & $"$ & -1.05 & +28.19 \\
\hline $46-3$ & $1510.0-1520.0$ & $n$ & +1.07 & +29.70 \\
\hline $47-1$ & $1520.0-1529.0$ & $"$ & +1.39 & +29.37 \\
\hline $48-2$ & $1529.0-1539.0$ & $"$ & +0.99 & +28.99 \\
\hline $50-1$ & $1548.0-1558.0$ & Berriasian & +0.80 & +29.20 \\
\hline $51-2$ & $1558.0-1567.0$ & Berriasian & - & - \\
\hline $52-2$ & $1567.4-1576.8$ & Berriasian & -0.10 & +24.21 \\
\hline $53-2$ & $1576.8-1586.2$ & Tithonian-Berriasian & +1.72 & +30.59 \\
\hline $57-1$ & $1615.0-1624.0$ & Tithonian & +2.10 & +30.19 \\
\hline
\end{tabular}

aOne sample measured from each interval.

Marine carbonates which are enriched in the light isotopes are often regarded as indicators of deposition in relatively warm waters. The variation of $\delta^{18} \mathrm{O}$ from 16.9 to 32.4 per mill established for the investigated Moroccan Basin deposits is, however, too great to be explained by reasonable temperature variations or by the fluctuations of oceanic-water isotopic composition.

Another cause for a high ${ }^{16} \mathrm{O}$ content is related to diagenesis of the carbonate sediment. The recrystallization of carbonates accompanied by isotopic exchange between the carbonate oxygen and the pore water oxygen at temperatures higher than the deposition temperature may result in enrichment in ${ }^{16} \mathrm{O}$. This process probably explains the trend, seen in some profiles, in which the carbonates are enriched in ${ }^{16} \mathrm{O}$ with depth (Anderson and Schneidermann, 1973). We are uncertain of the role of this factor in the $\delta^{18} \mathrm{O}$ variation observed in sediments of Holes 415A and 416A. No consecutive enrichment, however, of the light-isotope carbonate takes place with depth. Rather, the opposite trend occurs in the lower part of Hole 416A.

Carbonates enriched in light oxygen isotopes are characteristic of intracontinental basins. The content of the light oxygen isotopes is higher in fresh water than in oceanic waters. Correspondingly, the carbonates deposited in fresh-water basins or those previously subjected to diagenesis in the presence of meteoric waters have lower $\delta^{18} \mathrm{O}$ values than those deposited in typical marine environments (Weber et al., 1964). The carbon of freshwater carbonates is also enriched in the light isotope, be- cause the source of bicarbonate in intracontinental basins is mainly the isotopically light carbon dioxide of the soil (Galimov, 1968).

We can, therefore, assume that the low $\delta^{18} \mathrm{O}$ and $\delta^{18} \mathrm{C}$ values observed in the investigated sequence are caused by a continental origin of the carbonate material. And, indeed, the Valanginian-Hauterivian interval of Hole $416 \mathrm{~A}$, characterized by the lowest $\delta^{18} \mathrm{O}$ and $\delta^{13} \mathrm{C}$ values, constitutes a packet of terrigenous turbidites with little calcareous material which has undoubtedly been redeposited. Detrital material from the continent predominates in this interval.

We can estimate the degree of continental contribution to the sediment from the isotopic composition of organic carbon (see Galimov, Kodina, et al., this volume). Comparison of the isotopic composition of organic carbon with the $\delta^{18} \mathrm{O}$ and $\delta^{13} \mathrm{C}$ values in carbonates within the same interval does not show any close correlation. This is evidently because the carbonate and the organic matter were studied in different samples from within the interval. The heterogeneity of a single core section is such that, even within a small interval, sediments of different origin can be encountered. This once again emphasizes that the results of analysis of individual samples cannot be regarded as characterizing a more, or less, extensive interval of the section. A reasonable number of samples, however, taken together, can reflect the predominant features of the corresponding interval. In this sense, the organic-geochemistry data and the isotopic data for carbonate are in agreement. The intervals where carbonates enriched in the light isotopes of oxygen and carbon are often encountered correspond to the intervals where organic matter of continental origin predominates.

The enrichment of carbonates in the light oxygen and carbon isotopes is associated with continental origins, whereas the parallelism between the $\delta^{18} \mathrm{O}$ and $\delta^{13} \mathrm{C}$ variations, mentioned above, can have two causes: (1) variations of the ratios between the relatively isotopically light continental and the isotopically heavy marine carbonate in the sediment and (2) the difference in the isotopic composition of the continental carbonate as a result of the conditions in the primary sedimentation basin.

The oxygen- and carbon-isotope compositions in the shells of organisms are controlled by basically different factors. Thus we would not expect any correlation between the isotopic composition of carbon and oxygen at the time typical marine carbonate sediments of a single facies were being formed. Such a correlation becomes possible when a certain proportion of the carbonate material, formed or initially deposited in a different environment, is introduced. When we speak of the correlation of $\delta^{18} \mathrm{O}$ and $\delta^{18} \mathrm{C}$ in oceanic sediments, we mean, therefore, that a certain amount of the influent material originated on the continent. Figures 3 and 4 show a rather close correlation of $\delta^{18} \mathrm{O}$ and $\delta^{13} \mathrm{C}$ values in the bottom parts of Holes 415A and 416A, which comprise lithologically very heterogeneous sediments. We did not detect such a correlation in the top parts of the section, where the carbonate material is predominantly pelagic. 


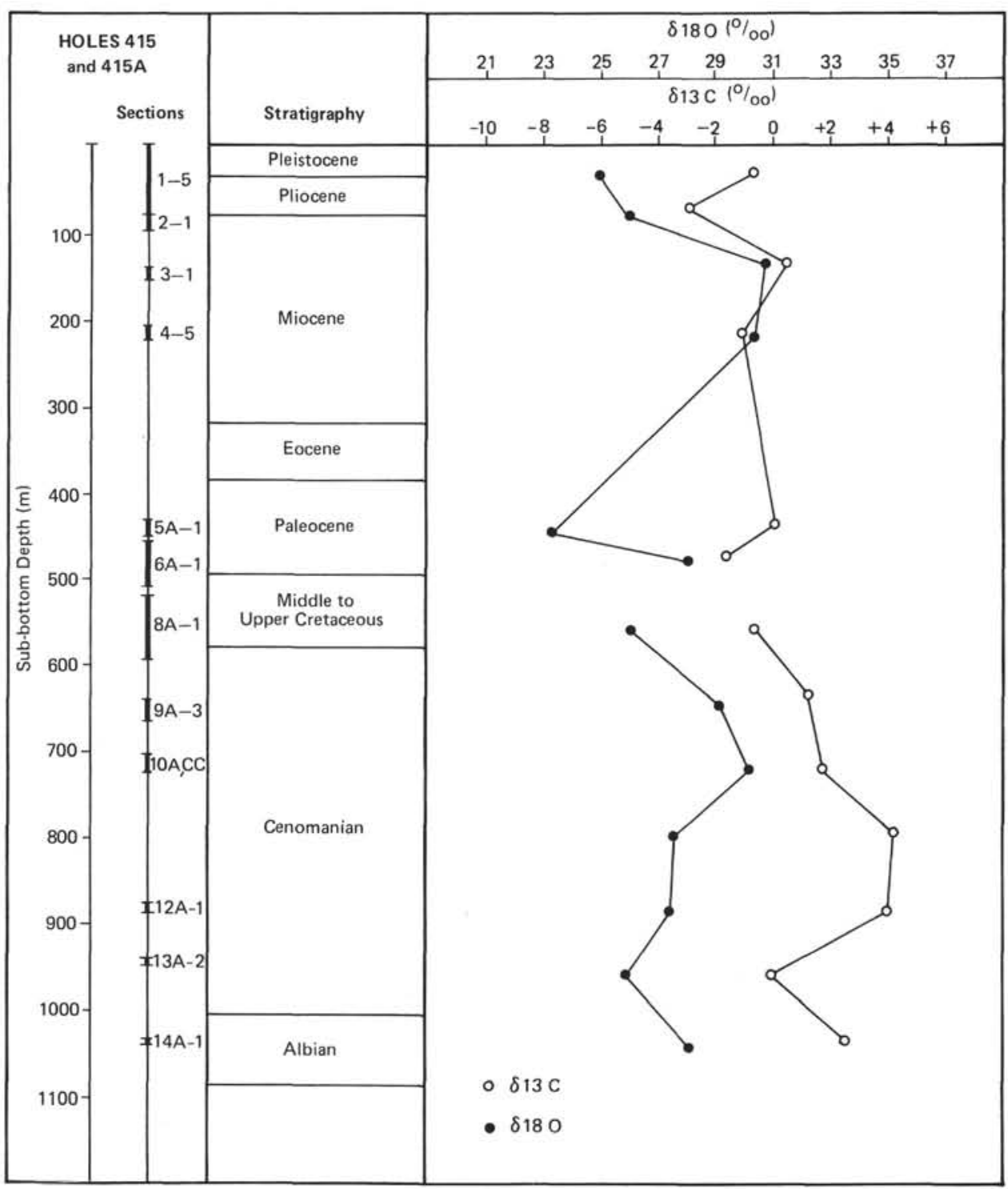

Figure 1. Variations in carbon and oxygen isotopic composition of the carbonates with depth, Holes 415 and $415 \mathrm{~A}$.

The effect of the continental-material influx probably explains the correlations of the $\delta^{18} \mathrm{O}$ and $\delta^{13} \mathrm{C}$ values obtained in the profiles of some other DSDP sites. Anomalously low $\delta^{18} \mathrm{O}$ values are associated with reduced $\delta^{13} \mathrm{C}$ values throughout the sequences at Sites 225 (Leg 23), 167 and 171 (Leg 17), 146 and 153 (Leg $15)$. In the corresponding intervals, an increase of the terrigenous component and reduction in $\delta 13 \mathrm{C}$ values are observed. In the cases where $\delta^{18} \mathrm{O}$ values lie within the limits explainable by climatic variation, the variation of $\delta^{18} \mathrm{O}$ and $\delta^{13} \mathrm{C}$ values is not parallel (Eade and Anderson, 1975; Douglas and Savin, 1975).

The contribution of continental material may have also caused the Coniacian-Santonian "oxygen isotopic shift" noted in geochemical profiles of oceanic deposits from a number of areas (Coplen and Schlanger, 1973). An increase of the continental-material transport as a result of increased tectonic activity during a specific period is more likely to cause the isotopic shift than a global short-term increase of oceanic water temperature by $7^{\circ} \mathrm{C}$, as assumed to have taken place by Coplen and Schlanger (1973).

\section{REFERENCES}

Anderson, T. F. and Schneidermann, N., 1973. Stable isotope relationships in pelagic limestones from Central Caribbean. In Edgar, N. T., Saunders, J. B., et al., Initial Reports of the Deep Sea Drilling Project, v. 15: Washington (U. S. Government Printing Office), p. 795-804.

Coplen, T. B. and Schlanger, S. O., 1973. Oxygen and carbon isotope studies of carbonate sediments from Site 167, Magellan Rise, Leg 17. In Winterer, E. L., Ewing, J. I., et al., Initial Reports of the Deep Sea Drilling Project, v. 17: Washington (U. S. Government Printing Office), p. 505509. 


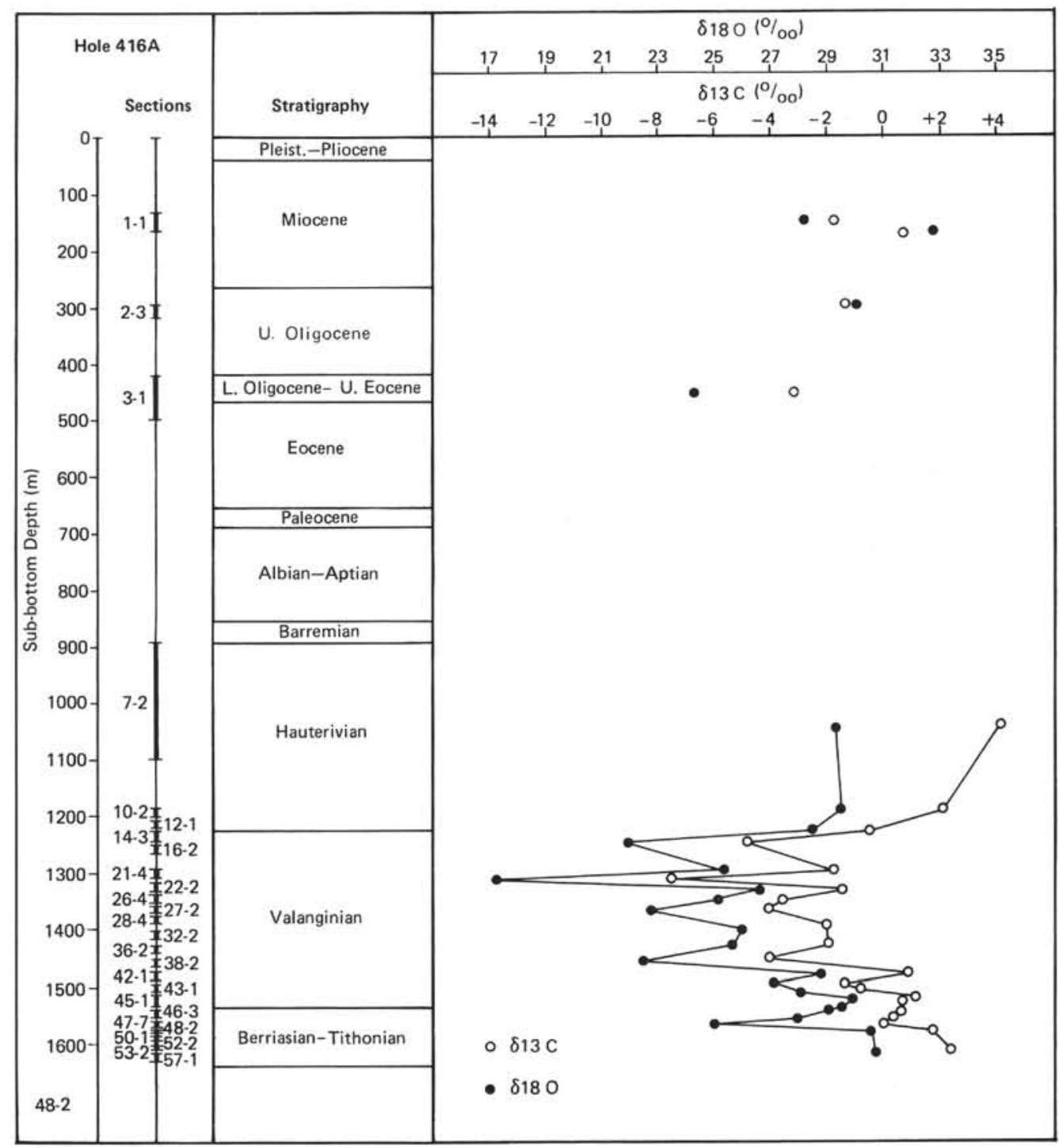

Figure 2. Variations in carbon and oxygen isotopic composition of carbonates with depth, Hole 416 A.

Douglas, R. G. and Savin, S. M., 1975. Oxygen and carbon isotope analyses of Tertiary and Cretaceous microfossils from Shatsky Rise and other Sites in the North Pacific ocean. In Larson, R. L., Moberly, R., et al., Initial Reports of the Deep Sea Drilling Project, v. 32: Washington (U. S. Government Printing Office), p. 509-520.

Eade, J. V. and Anderson, T. F., 1975. Oxygen and carbon isotope composition and diagenesis of Eocene clay nannochalk at DSDP Site 287, Coral Sea Basin, Leg 30. In Andrews, J. E., Packham, G., et al., Initial Reports of the Deep Sea Drilling Project, v. 30: Washington (U. S. Government Printing Office), p. 419-422.
Galimov, E. M., 1968. Geochemistry of stable carbon isotopes (in Russian): Moscow (Nedra).

Keith, M. L., Anderson, G. M., and Eichler, R., 1964. Carbon and oxygen isotopic composition of mollusk shells from marine and fresh-water environments, Geochimica et Cosmochimica Acta, v. 28, p. 1757-1786.

Lawrence, J. R., 1974. Stable oxygen and carbon isotope variations in the pore waters, carbonates and silicates, Sites 225 and 228 , Red Sea. In Whitmarsh, R. B., Weser, O. E., et al., Initial Reports of the Deep Sea Drilling Project, v. 23: Washington (U. S. Government Printing Office), p. 939942. 

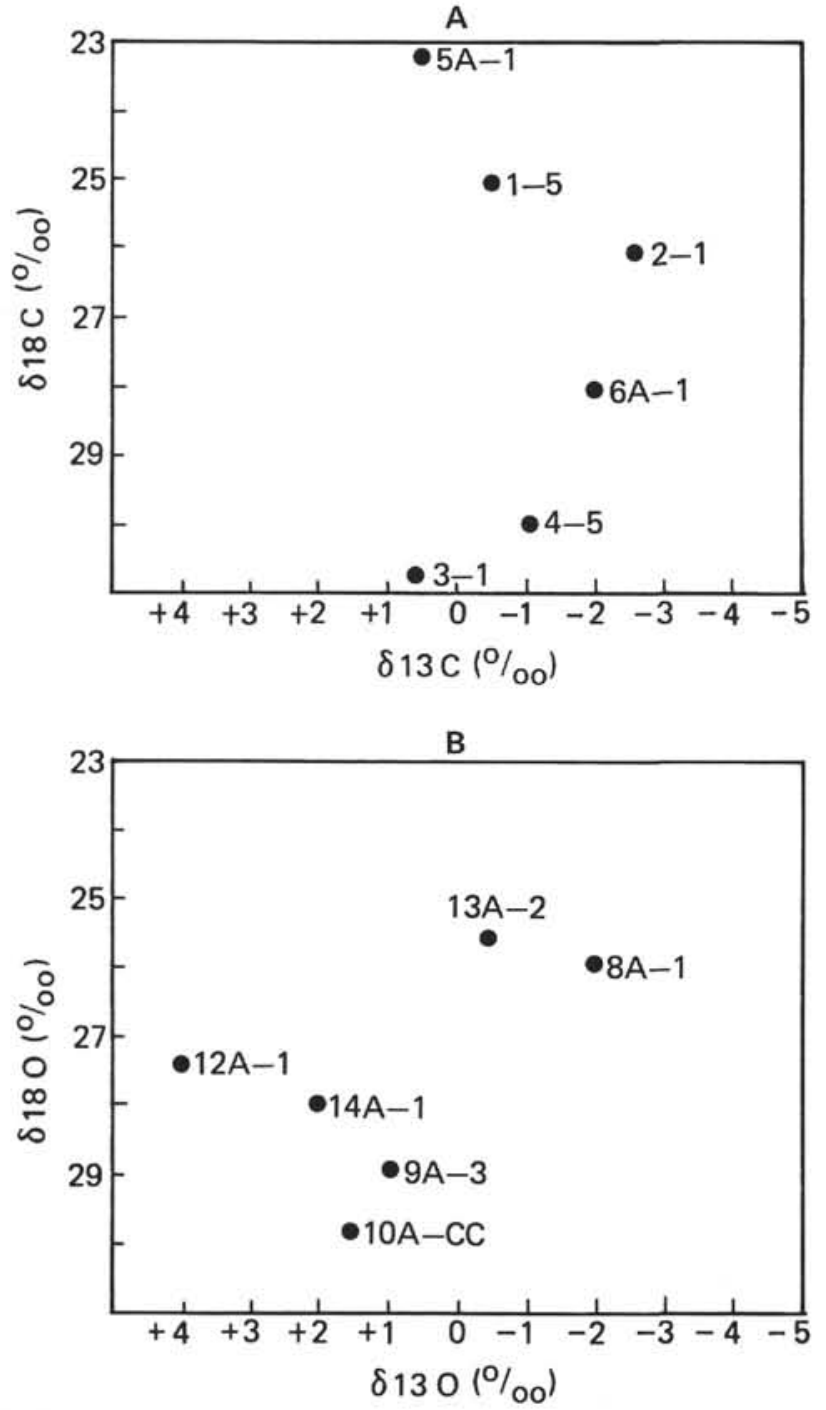

Figure 3. $\delta^{13} \mathrm{C}$ versus $\delta^{18} \mathrm{O}$ of carbonates, Holes 415 and 415A. (A) Upper section of the site (down to $509 \mathrm{~m}$ ), (B) lower section of the site (sub-bottom depth 509$1041 \mathrm{~m})$.
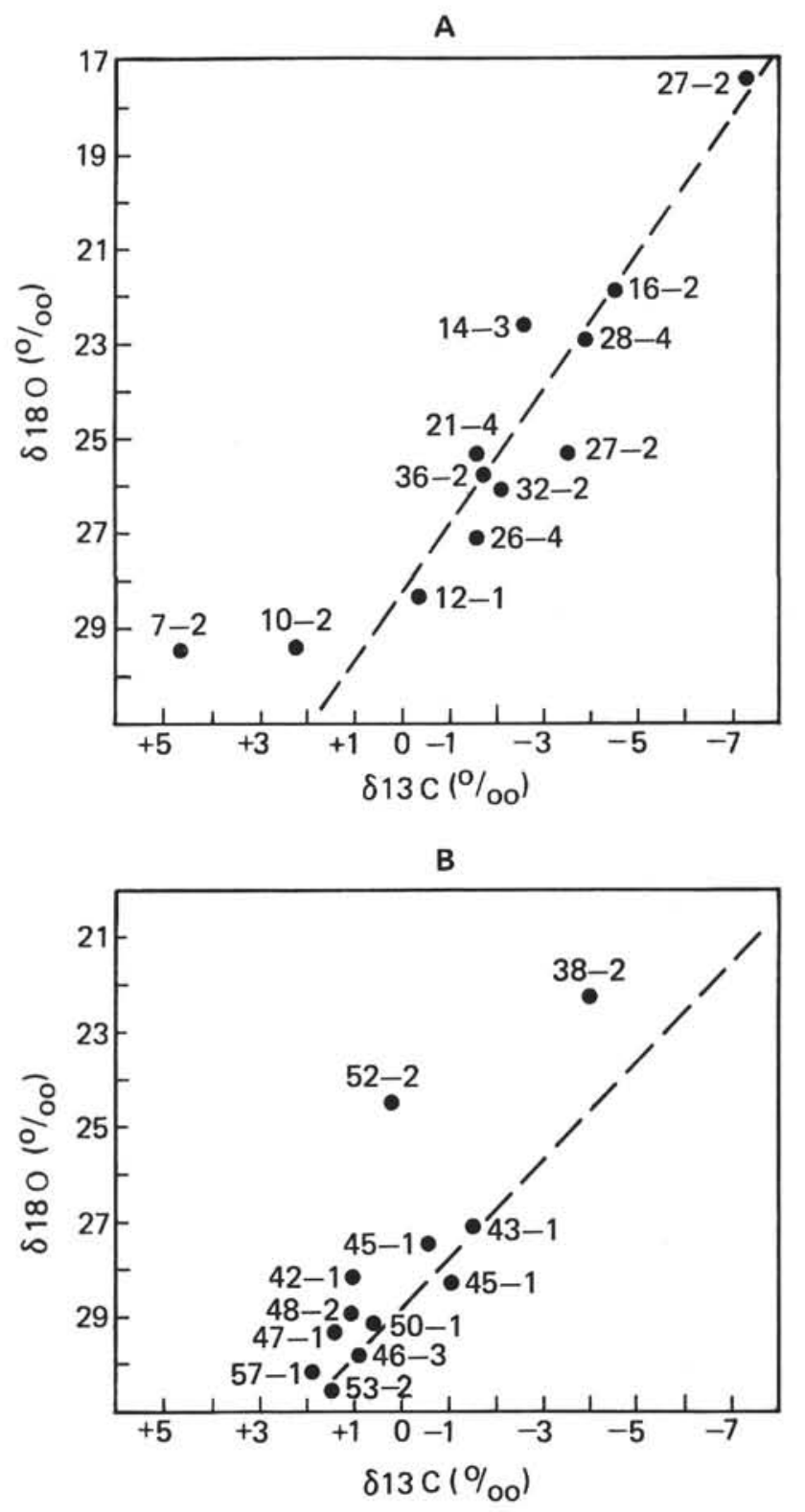

Figure 4. $\delta^{13} \mathrm{C}$ versus $\delta^{18} \mathrm{O}$ of carbonates, Hole $416 \mathrm{~A}$. (A) Sub-bottom depth 880-1430 meters, (B) sub-bottom depth 1430-1624 meters. 